\title{
Comparison of milk and maize based diets in kwashiorkor
}

\author{
D R Brewster, M J Manary, I S Menzies, R L Henry, E V O’Loughlin
}

College of Medicine, University of Malawi, Blantyre, Malawi D R Brewster

Washington University School of Medicine, St Louis, USA

M J Manary

Department of Clinical Biochemistry, King's College Medical

School, London I S Menzies

Faculty of Medicine and Health Sciences, University of

Newcastle, Australia

R L Henry

New Children's Hospital, University of Sydney, Westmead, Australia

E V O'Loughlin

Correspondence to: Dr David Brewster, Flinders University and Maternal and Child Health, Royal Darwin Hospital, PO Box 41326, Casuarina, NT 0811, Australia.

Accepted 16 September 1996

\begin{abstract}
The dual sugar test of intestinal permeability is a reliable non-invasive way of assessing the response of the small intestinal mucosa to nutritional rehabilitation.

Aim-To compare a local mix of maizesoya-egg to the standard milk diet in the treatment of kwashiorkor.

Design-The diets were alternated three monthly in the sequence milk-maizemilk. There were a total of 533 kwashiorkor admissions of at least five days during the study who received either milk or maize. Intestinal permeability was assessed at weekly intervals by the lactulose-rhamnose test in 100 kwashiorkor cases, including 55 on milk and 45 on the maize diet.

Results-Permeability ratios (95\% confidence interval) on the milk diet improved by a mean of $6.4(1.7$ to 11.1$)$ compared with $-6.8(-16.8$ to 5.0$)$ in the maize group. The improved permeability on milk occurred despite more diarrhoea, which constituted $34.8 \%$ of hospital days (29.8 to 39.8 ) compared with $24.3 \%(17.8$ to 30.8$)$ in the maize group. Case fatality rates for all 533 kwashiorkor admissions were $13.6 \% v$ $20.9 \%$, respectively, giving a relative risk of death in the maize group of 1.54 (1.04 to 2.28). The maize group also had more clinical sepsis $(60 \% v 31 \%)$ and less weight gain $(2.9 v 6.4 \mathrm{~g} / \mathrm{kg} / \mathrm{day})$ than the milk group.

Implications-Milk is superior to a local maize based diet in the treatment of kwashiorkor in terms of mortality, weight gain, clinical sepsis, and improvement in intestinal permeability.

(Arch Dis Child 1997;76:242-248)
\end{abstract}

Keywords: kwashiorkor; intestinal permeability; Africa.

Childhood malnutrition is a major health problem in Malawi. In a study of children aged 24-59 months, $69.3 \%$ of poor urban children and $83.2 \%$ of low income rural children were stunted (height for age $<2 \mathrm{z}$ scores). ${ }^{1}$ A review of hospital admissions over 12 months in Blantyre in 1992-3 revealed that severe malnutrition was the principal diagnosis in $11 \%$ of all paediatric admissions, and had a $36.4 \%$ case fatality rate (378/1039). ${ }^{2}$ Although this indicates a severe spectrum of disease, it also suggests a need for improved case management.
This study focuses on the diet in nutritional rehabilitation of kwashiorkor. Milk has been accepted as appropriate treatment of kwashiorkor at least since a 1956 South African study showed improvement on skim milk without supplemental vitamins, and a milk based diet is still the recommended treatment. ${ }^{34}$ Nevertheless, there are many reports of satisfactory results with the use of local cereal mixes in the treatment of persistent diarrhoea and/or malnutrition. ${ }^{5-7}$ Moreover, donor agencies at a country level question the appropriateness of milk in nutritional rehabilitation due to problems of lactose intolerance, cows' milk allergy, and the higher cost than local staple foods. The supply of milk powder to Malawi has been cut back by the World Food Program, so it was important for us to study an alternative diet based on maize, which is the staple diet in Malawi.

The aim of this study was to evaluate the recovery of intestinal function as measured by the lactulose-rhamnose (L-R) test in children with kwashiorkor on two different diets of similar energy and protein content (table 1). One diet was the standard milk based diet; the other a cereal-based diet of maize soya blend (likuni phala) to which egg was added to increase protein content and quality. These diets were chosen as feasible alternatives in this setting, as low lactose formulas and commercial weaning foods are too expensive. A further aim was to evaluate the importance of cows' milk allergy with the use of milk to treat kwashiorkor. Cows' milk allergy is associated with increased intestinal permeability. ${ }^{8}$ Postenteritis cows' milk allergy is a common feature of chronic diarrhoea leading to a biopsy in the UK, and may contribute to persistent diarrhoea with malnutrition in African children. $^{9}{ }^{10}$

\section{Patients and methods}

Out of 149 children with kwashiorkor in whom permeability testing was done, 76 were treated with a milk based diet, 64 with an exclusively maize based (milk free) diet, and nine with both diets over a changeover period. Repeat testing was not done in 21 children in the milk group and 19 in the maize group due to early death or being taken from hospital before discharge, leaving 100 subjects for comparison. The method of evaluating intestinal permeability by the L-R test has been described in the previous article, involving overnight testing for a mean of 7.6 hours. L-R ratios were done at 
Table 1 The energy and protein content of milk and maize based diets

\begin{tabular}{|c|c|c|c|c|c|c|}
\hline \multirow[b]{2}{*}{ Milk preparations } & \multicolumn{2}{|c|}{ Ingredients ( $g$ ) } & \multicolumn{2}{|c|}{ Energy (kf) } & \multicolumn{2}{|c|}{ Protein (g) } \\
\hline & Milk & Maize & Milk & Maize & Milk & Maize \\
\hline Premix (per 100 g) & - & - & 2108 & 1646 & 18.0 & 11.4 \\
\hline Skim milk & 50 & - & 163 & - & 3.96 & - \\
\hline Sugar & 23 & 19 & 79 & 79 & - & - \\
\hline Oil & 27 & 4 & 223 & 37 & - & - \\
\hline Maize $\operatorname{mix}^{\star}$ & - & 77 & - & 312 & - & 2.96 \\
\hline Phase 1 (per 1) & - & - & 2780 & 3049 & 10.2 & 14.2 \\
\hline Premix $†$ & 56.5 & 71.5 & 1193 & 1176 & 10.2 & 8.2 \\
\hline Sugar & 101 & 101 & 1588 & 1588 & - & - \\
\hline Egg & - & 50 & - & 286 & - & 6 \\
\hline Phase 2 (per 1) & - & - & 4763 & 5279 & 40.7 & 44.6 \\
\hline Premix $\dagger$ & 226 & 286 & 4763 & 4708 & 40.7 & 32.6 \\
\hline Egg & - & 100 & - & 571 & - & 12 \\
\hline
\end{tabular}

* Maize $80 \%$, soya $20 \%$ as likuni phala.

† Measured by volume as $100 \mathrm{ml}$ (phase 1) or $400 \mathrm{ml}$ (phase 2).

weekly intervals in hospital, with a total of 144 tests in the milk group and 117 in the maize group.

The milk and maize diets were similar in energy and protein densities, and were formulated into two separate phases of treatment; phase 1 for initiation of cure and phase 2 for rapid growth, which was generally started during the second week with clinical improvement (table 1). The energy dense maize porridge was thinned with germinated millet flour after cooking to improve palatability and intake. Lactose intolerance was not measured directly in the study, as our initial phase 1 milk diet contained only $14.5 \mathrm{~g} / 1$ of lactose. However, lactose was also measured in urine during testing, and was separated from lactulose on thin layer chromatography. After standard treatment, all children received co-trimoxazole, albendazole, and supplements of potassium, magnesium, zinc, and other micronutrients.

Due to constraints of nursing care and logistics in this setting, we could neither randomise patients into milk and maize diets, nor blind health workers about the diets. Consequently, the two diets were given alternately, using only one at a time. The timing of the maize based diet was determined by the shortage of milk supply. As skim milk powder from the World Food Program was unavailable in April, we gave the maize based diet from April to June,

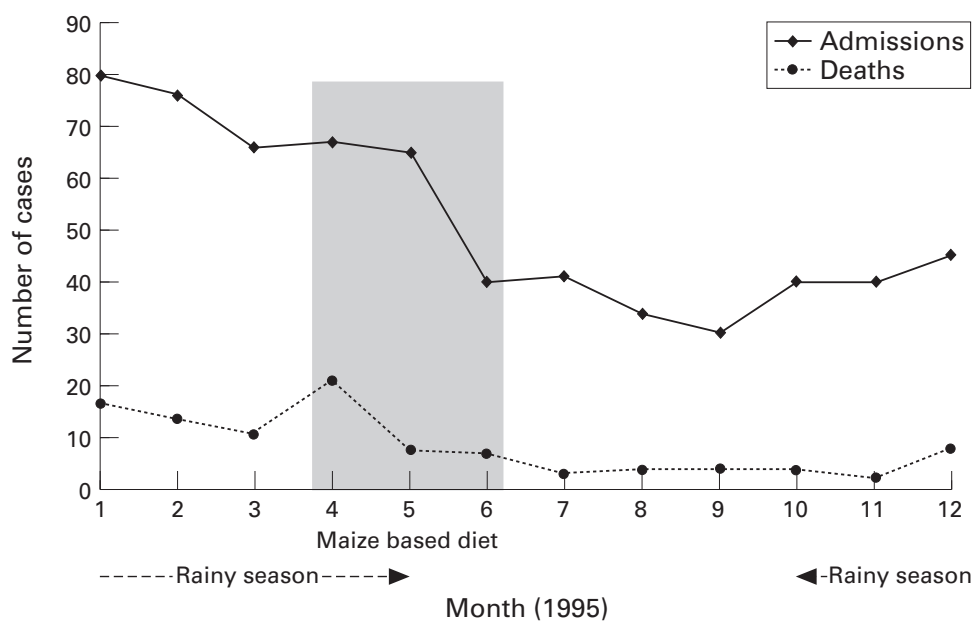

Figure 1 Monthly variations in admissions and deaths for 533 kwashiorkor admissions of more than five days' duration from Fanuary to December 1995. which just overlapped the main seasonal change in malnutrition prevalence (fig 1). The milk diet, as the standard treatment, was given January to March and July to September. The level of nursing care was not improved for the study, so mothers continued to feed and care for their children in the usual manner for this nutrition centre. Nasogastric tube feeding was not used due to systematic refusal by mothers at this nutrition centre. Clinical sepsis was defined as fever, respiratory distress, a change in mental status, shock, or any abrupt deterioration in condition, but was not confirmed due to the limited microbiology resources in this setting. Data analysis was as described in the preceding article.

The study was approved by the Health Sciences Research Committee of Malawi. Informed verbal consent was obtained in the local language from a parent or guardian before permeability testing, and it was made clear that non-participation would not affect the child's treatment. The maize diet in this study was imposed by a lack of supply of dried skim milk. It was important for us to evaluate the use of a maize based diet in kwashiorkor as milk supply to Nutrition Rehabilitation Centres in Malawi was being cut back by the World Food Program and periods of non-supply were increasingly common. Thus, this study was done to see whether a local cereal based diet was as good as milk in the management kwashiorkor, so as to give guidance to the Health Department and donor agencies about food supplies to Nutrition Rehabilitation Centres for the treatment of kwashiorkor.

\section{Results}

Table 2 compares the two dietary groups on admission, showing that the parents of the maize group were better educated and of higher socioeconomic status than the milk group. There were no other significant baseline differences detected between the groups.

It was evident clinically during the study that the maize based diet was not as successful treatment for kwashiorkor as milk. For all 533 kwashiorkor admissions of at least five days during the study, the milk group had a lower mortality, less sepsis, and better weight gain than the maize group. Thus, the maize group had a $58.1 \%$ prevalence $(100 / 172)$ of clinical sepsis compared with $45.7 \%$ (165/361) for milk, giving a relative risk of sepsis for maize of 1.30 (95\% confidence interval (CI) 1.06 to 1.58). The mean weight gain in $z$ scores after resolution of oedema for the milk group was 0.40 (CI 0.34 to 0.46 ) compared with 0.25 (CI 0.15 to 0.35$)$ for maize $(\mathrm{p}=0.00008)$. The case fatality rate was $20.9 \%(36 / 172)$ for maize and $13.6 \%(49 / 361)$ for milk, for a relative risk of death for the maize diet of 1.54 (CI 1.04 to 2.27).

For the 100 kwashiorkor cases with repeat permeability tests, there was also a higher mortality rate in the maize than the milk group $(10 / 45 v 2 / 55)$, for a relative risk of death for maize of 6.3 (1.4 to 25.0). This increased risk of late death on a maize diet remained 
Table 2 Baseline comparison of malnutrition cases: milk $v$ maize based diets

\begin{tabular}{llll}
\hline Feature & Milk diet $(n=55)$ & Maize diet ( $n=45)$ & p Valuet \\
\hline Age (months) & $29.8(25.1$ to 34.6$)$ & $27.0(19.5$ to 30.8$)$ & 0.78 \\
Travel time (min) to hospital & $59.2(39.7$ to 78.7$)$ & $65.8(49.9$ to 81.7$)$ & 0.80 \\
Socioeconomic status score & $13.6(12.4$ to 14.8$)$ & $15.4(14.1$ to 16.7$)$ & 0.04 \\
Family size (members) & $4.6(4.2$ to 5.1$)$ & $4.5(3.8$ to 5.1$)$ & 0.98 \\
Still breast fed (\%) & $1(1.8)$ & $5(11.1)$ & 0.09 \\
Previous malnutrition admission (\%) & $10(18.2)$ & $9(20.0)$ & 0.98 \\
Previous child deaths (\%) & $25(45.5)$ & $14(31.1)$ & 0.18 \\
Days of diarrhoea before admission & $12.0(8.2$ to 15.7$)$ & $12.1(7.5$ to 16.7$)$ & 0.96 \\
Days oedema before admission & $14.2(11.7$ to 16.8$)$ & $15.0(10.6$ to 19.4$)$ & 0.75 \\
No kwashiorkor rash (\%) & $24(43.6)$ & $22(48.9)$ & 0.75 \\
AIDS (\%) & $11(20.0)$ & $11(24.4)$ & 0.77 \\
Mother's schooling (mean years) & $3.1(2.2$ to 3.9$)$ & $5.3(4.3$ to 6.3$)$ & 0.001 \\
Father has skilled job (\%) & $20(37.0)$ & $25(55.6)$ & 0.10 \\
Wasting (WHZ) mean z score & $-1.9(-2.2$ to -1.6$)$ & $-2.1(-2.4$ to -1.8$)$ & 0.36 \\
$\quad$ No wasted (<-2 SD) (\%) & $27(49.1)$ & $23(51.1)$ & 0.91 \\
Stunting (HAZ) mean z score & $-3.6(-4.0$ to -3.2$)$ & $-3.4(-3.8$ to -3.1$)$ & 0.53 \\
$\quad$ No stunted (<-2 SD) (\%) & $48(87.3)$ & $41(91.1)$ & 0.75 \\
\hline
\end{tabular}

* Geometric mean (95\% confidence interval).

t $\mathrm{p}$ Values are $\chi^{2}$ for frequency counts and $t$ tests for measurements (Yates's correction).

$\mathrm{HAZ}=$ height for age $\mathrm{z}$ score; $\mathrm{SD}=$ standard deviation ( $\mathrm{z}$ score); WHZ = weight for height $\mathrm{z}$ score .

Table 3 Results of kwashiorkor cases: milk v maize diet

\begin{tabular}{|c|c|c|c|}
\hline Outcomes & Milk diet $(n=55)$ & Maize diet $(n=45)$ & $p$ Value \\
\hline \multicolumn{4}{|l|}{ Clinical } \\
\hline Mortality (\%) & $2(3.6)$ & $10(22.2)$ & 0.01 \\
\hline Clinical sepsis (\%) & $17(30.9)$ & $27(60.0)$ & 0.01 \\
\hline Diarrhoea during initial week (\%) & $35(63.6)$ & $14(31.1)$ & 0.002 \\
\hline$\%$ Days with diarrhoea in hospital & $34.8(29.8$ to 39.8$)$ & $24.3(17.8$ to 30.8$)$ & 0.01 \\
\hline \multicolumn{4}{|l|}{ Weight gain: } \\
\hline Mean No of days & $5.3(3.9$ to 6.7$)$ & $2.7(1.7$ to 3.7$)$ & 0.01 \\
\hline In $\mathrm{g} / \mathrm{kg} /$ day $^{\star}$ & $4.4(3.4$ to 5.5$)$ & $2.9(2.1$ to 3.7$)$ & 0.03 \\
\hline Days in hospital & $15.5(13.9$ to 17.1$)$ & $15.8(13.9$ to 17.7$)$ & 0.81 \\
\hline Oedema resolved (days) & $9.3(7.7$ to 10.9$)$ & $8.8(6.6$ to 11.0$)$ & 0.71 \\
\hline \multicolumn{4}{|l|}{ Permeability } \\
\hline Mean urine output (ml/kg/hour testing) $)^{\star}$ & $1.29(1.13$ to 1.45$)$ & $1.21(1.05$ to 1.37$)$ & 0.51 \\
\hline Mean \% lactulose recovery ${ }^{\star}$ & $0.145(0.12$ to 0.17$)$ & $0.192(0.16$ to 0.23$)$ & 0.03 \\
\hline Mean \% rhamnose recovery ${ }^{\star}$ & $1.08(0.90$ to 1.29$)$ & $0.99(0.83$ to 1.19$)$ & 0.51 \\
\hline \multicolumn{4}{|l|}{ Differences in L-R permeability ${ }^{\star} \dagger$} \\
\hline Improved ratio $(\%)$ & $44(57.9)$ & $25(41.7)$ & 0.09 \\
\hline Worsened ratio $(\%)$ & $19(25.0)$ & $28(46.7)$ & 0.01 \\
\hline Mean differences in L- $\mathrm{R}$ ratio & $6.4(1.7$ to 11.1$)$ & $-6.8(-16.8$ to 5.0$)$ & 0.001 \\
\hline
\end{tabular}

* Geometric mean $(95 \%$ confidence interval), L-R ratios $\times 100$.

† Differences between weekly tests $1-2$ and $1-3$.

significant on logistic regression when controlled for diarrhoea and intestinal permeability (see table 2 of companion paper $^{11}$ ).

Overall on permeability testing, there was a significant $(\mathrm{p}=0.001)$ mean improvement in $\mathrm{L}-\mathrm{R}$ ratios in the milk group compared with the maize group (table 3, fig 2). After one week of nutritional rehabilitation, the geometric mean $(95 \%$ CI $)$ L-R ratio $(\times 100)$ improved in the milk group from 15.6 (12.4 to 19.6$)$ to 10.2 (7.8 to 13.3 ), whereas it worsened in the maize

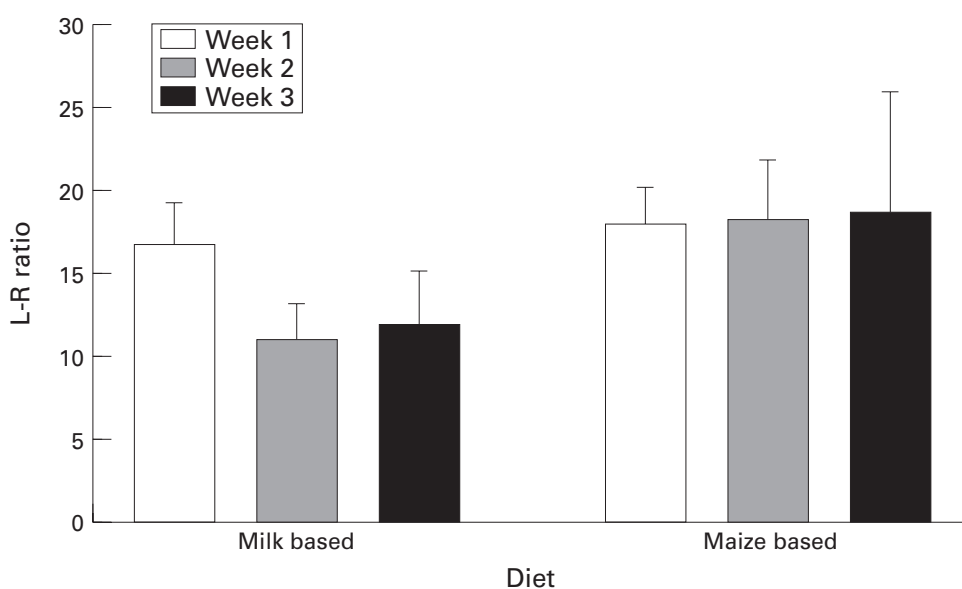

Figure 2 Weekly L-R ratios fore the milk and maize based diets in 100 kwashiorkor cases. group from 17.8 (14.6 to 21.7 ) to 19.2 (14.8 to 25.0). The improvement in permeability in the milk group occurred despite a significantly $(p=0.01)$ higher mean percentage of hospital days with diarrhoea (34.8\%, CI 29.8 to 39.8 ) compared with the maize group $(24.3 \%$, CI 17.8 to 30.8 ). Yet for the milk group as a whole, diarrhoea was still associated with a higher mean L-R ratio (18.9, CI 15.3 to 23.5) than for those without diarrhoea (9.9, CI 8.1 to11.9, $\mathrm{p}=0.00007)$. During the initial low density phase 1 diet, the diarrhoea prevalence was $60 \%$ on the milk diet compared with $27 \%$ for maize, whereas for both high energy phase 2 diets (milk and maize) it was only $24-25 \%$ (odds ratio 0.40 , CI 0.23-0.65). A milk diet remained a significant contributor to diarrhoea on logistic regression when controlled for intestinal permeability (table 2 of companion paper ${ }^{11}$ ).

The mean difference in L-R ratio between dietary groups was mainly accounted for by lactulose recovery, which was $0.15 \%(0.12$ to 0.18 ) for milk $v 0.21 \%$ (0.17 to 0.26$)$ for maize. On the other hand, the improvement in L-R ratios during nutritional rehabilitation with milk was due to improved rhamnose absorption (improved absorptive surface area). Diarrhoea impaired barrier function in the milk group as reflected by higher mean lactulose recovery $(0.19 \% v 0.12 \%, \mathrm{p}=0.01)$ whereas diarrhoea made less difference to lactulose recovery $(0.23 \% v 0.19 \%, \mathrm{p}=0.61)$ in the maize group.

\section{Discussion}

DIETARY TREATMENT

In this study, we compared a cows' milk diet to a 4:1 maize-soya blend with egg at a nutrition rehabilitation centre, focusing on clinical improvement. Maize, the Malawian staple, has a moderately low protein content with relative deficiency of lysine and tryptophan. We improved the protein quality of the maize diet in this study by adding soya and egg. Another approach is to use hybrid maize with the opaque-2 gene which has higher lysine and tryptophan content. The new quality protein maizes cause greater nitrogen retention, less faecal energy loss, and improved weight gain in the treatment of malnutrition compared with common maize. ${ }^{12}$ But enthusiasm for this approach waned because the new maize was not always culturally acceptable, poor subsistence farmers could not afford to grow it, and the 'protein fiasco' debate played down the importance of protein. ${ }^{13}$

Plant based diets are a cheaper source of protein than milk, so have been used to treat severe malnutrition. A study at a metabolic unit in Jamaica compared cows' milk with a soya formula (Sobee) in terms of resolution of wasting. ${ }^{14}$ Despite little difference in energy intake, weight gain was much greater in the cows' milk group, which was attributed to zinc deficiency limiting lean tissue synthesis on the soya formula. A further study compared high energy milk to the complex carbohydrate pectin in an attempt to boost metabolic activity of the colonic microflora, increase nitrogen salvage, and enhance lean tissue deposition. ${ }^{15}$ But 


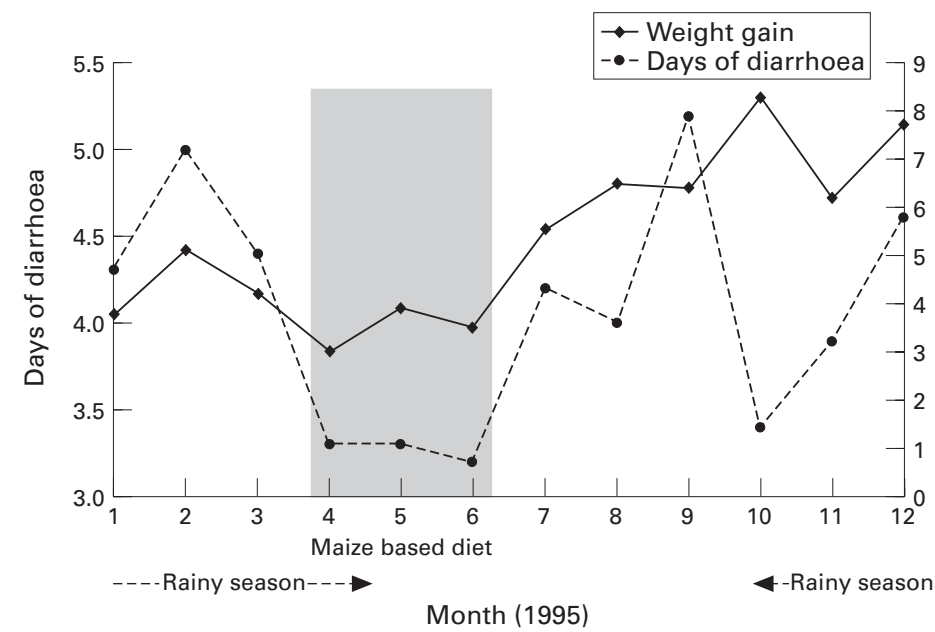

Figure 3 Monthly variations in weight gain and diarrhoeal duration in hospital for kwashiorkor admissions as in fig 1.

there was significantly less weight gain in the pectin group, which cast doubt on the use of locally available staples, which are rich in complex carbohydrates, for promoting rapid catch-up growth in malnourished children. Indian and South African studies used plant protein sources to rehabilitate malnourished children in the $1960 \mathrm{~s}$, but found them less efficient than milk protein in terms of oedema resolution, rise in serum albumin, and weight gain. ${ }^{16-18}$

Zinc deficiency is a particular concern for cereal-legume diets due to the high phytate content. Plant based diets are an important source of phytic acid, a myoinositol hexaphosphate in fibre which is found in unrefined cereals (for example maize), seeds, nuts, legumes, some fruits, and tubers. It complexes with divalent cations, forming insoluble compounds in the intestine which inhibit the absorption of certain trace elements, particularly zinc. Dietary studies of Malawian children have documented the high phytate content of the maize diet leading to zinc deficiency. ${ }^{19}$ Intestinal permeability is known to be increased with zinc deficiency, mainly due to increased lactulose permeation. ${ }^{20}$ In the present study, however, zinc was unlikely to be limiting since our subjects were supplemented with $40 \mathrm{mg}$ /day and the maize was germinated.

Germination of cereals has several advantages. It acts by activating amylase and phytase enzymes which break the starch down into sugars and reduce the phytate content, leading to a more liquid porridge of lower viscosity and greater palatability. This resulted in $30-40 \%$ increases in energy intake in studies from Bangladesh, ${ }^{21}$ India, ${ }^{7}$ and Tanzania. ${ }^{22}$ Although a Jamaican study did not find much increase in mean energy intake on $\alpha$-amylase 'thinned' maize porridge, ${ }^{23}$ it did halve mean feeding times, which would have led to bigger differences in intake in a setting where feeds are less well supervised than in a research unit. However, a definite disadvantage of cereal based porridge compared with milk in kwashiorkor with severe anorexia is the difficulty with tube feeding, as even thinned porridge is too thick for usual nasogastric tubes.

The present study is further evidence against a local staple diet, but in this study the focus was on the treatment of kwashiorkor where the main aim was clinical improvement (resolution of oedema, infection, and anorexia) rather than catch-up growth. Our median hospital stay for kwashiorkor survivors was only 15 days, so children were not kept in hospital until wasting had resolved. Out of the $62 \%$ of children who gained weight in hospital, the mean weight gain after resolution of oedema was only $479 \mathrm{~g}$ (414-556) and $29 \%$ of cases went home before wasting had completely resolved. The length of hospital treatment for severe malnutrition has been addressed by two Caribbean studies with conflicting results about the benefit of prolonged hospitalisation. ${ }^{24}{ }^{25}$ In any case, prolonged hospital treatment until wasting has completely resolved is not feasible in Malawi, particularly in the AIDS era.

\section{LACTOSE INTOLERANCE}

The activity of brush border disaccharidases is generally depressed in malnutrition, particularly lactase levels in kwashiorkor. ${ }^{26}$ The severity of histological changes in the mucosa may not correspond to lactase levels because they may be only patchy in distribution or only affect microvillus surface area. ${ }^{27-29}$ On scanning electron microscope, there may be an excess of mucus covering the mucosal surface, loss of glycocalyx, increased cell shedding, or adherent micro-organisms on the mucosal surface. ${ }^{30}$ From a clinical perspective, disaccharidase activity may not correlate with clinical intolerance of milk, although low levels usually cause increased stool weight. On the other hand, a Zairean study of severe malnutrition implicated dietary lactose and milk protein in aggravating malabsorption, leading to dehydration, hypokalaemia and acidosis. ${ }^{31}$ This picture of lactose intolerance with biochemical disturbances from osmotic diarrhoea is also common in rural Aboriginal Australian children with malnutrition and breast feeding, ${ }^{32}$ but is uncommon at nutrition rehabilitation centres using standard dietary treatment in the developing world. Many studies have concluded that milk was not contraindicated in severe malnutrition despite higher stool volumes, because it did not hamper clinical recovery. ${ }^{33-35}$

In addition to assessment of permeability, sugar probes can also be used to assess brush border disaccharidases, such as by the lactoselactulose ratio. This ratio was not a reliable indicator of lactase activity in this study because of the differing dietary lactose content of the diets. Nevertheless, the excess diarrhoea in the milk group is likely to be related to lactose intolerance, since it was associated with lactosuria and cannot be explained by seasonal factors (fig 3). This was an unexpected finding as lactose intolerance did not seem to be a clinical problem with the low lactose intake $(1.7 \mathrm{~g} / \mathrm{kg} /$ day $)$ of a phase 1 milk diet. Surprisingly, the change to high energy milk with increase in lactose intake to $8.7 \mathrm{~g} / \mathrm{kg} /$ day was not associated with an increase in diarrhoea, suggesting that lactase 
activity improves quicker with nutritional rehabilitation than abnormal permeability. This is consistent with the concept of a threshold for lactose intolerance, which improves during the initiation of cure. ${ }^{36}$ Although special low lactose or elemental formulas are too expensive for use in this setting, our results suggest that recovery of gut integrity during the initial treatment phase of kwashiorkor would benefit from a lower lactose milk formula, such as K-mix-II. ${ }^{37}$

COWS' MILK PROTEIN ALLERGY

Allergy to cows' milk has been another concern about the use of milk in nutritional rehabilitation of children with enteric infections. Some children with postenteritis enteropathy in developed countries, particularly from traveller's diarrhoea, have a superimposed cows' milk sensitive enteropathy, related to a local gut or even systemic immunodeficiency state. ${ }^{38} 39 \mathrm{Al}-$ though the clinical importance of postinfectious dietary protein intolerance has been questioned, ${ }^{40}$ a London study reported that cows' milk sensitive enteropathy accounted for $68 \%(92 / 135)$ of mild-moderate enteropathy cases with prolonged diarrhoea leading to a biopsy. ${ }^{9}$

In the developing world, the syndrome of persistent diarrhoea with malnutrition was investigated in The Gambia, ${ }^{101}$ where the morphological changes were consistent with a cell mediated immune form of damage from dietary, protozoal or bacterial antigens, which suggested the possibility of cows' milk protein intolerance. Although cows' milk allergy has been documented in the developing world, the circumstances have been atypical (for example artificially fed urban infants of high or unspecified socioeconomic status). ${ }^{42} 43$

Permeability testing has been done in cows' milk allergy with enteropathy, showing a significant rise in ratios with milk challenge compared to non-allergic children. ${ }^{84-46}$ The clinical severity correlated directly with the degree of abnormal permeability, which was mainly due to increased lactulose permeation. These findings lend plausibility to the suggestion that persistent diarrhoea with malnutrition in the African context may have an element of postenteritis cows' milk allergy, so we designed the present study to examine this question.

Our results go against cows' milk allergy playing a significant part with the use of cows' milk to treat kwashiorkor in this setting. The milk group had improved permeability despite a higher prevalence of diarrhoea than the nonmilk diet group. Although the excess diarrhoea during the phase 1 milk diet might be explained as milk allergy, it was too transient for milk protein intolerance without milk withdrawal. Moreover, kwashiorkor is a disease of the weaning period, with a mean age of 28 months in this study, whereas cows' milk allergy tends to occur at a younger age. Of course, it might also be argued that the maize group had a food sensitive enteropathy from soya or egg. This seems unlikely, however, as the diarrhoea prevalence was low on that diet and atopic manifestations are uncommon in this setting of endemic malaria, high exposure to bacterial infections and poor nutritional status. $^{47}$

We can only speculate about the reason for increased intestinal permeability in kwashiorkor treated with a maize based diet. Increased lactulose permeation was the main contributor to the mean difference in L-R ratios between milk and maize groups, so rather than a poorly absorbed solute in maize inhibiting rhamnose absorption, it suggests that maize is associated with a defect of mucosal barrier function. This is not likely to be related to differences in micronutrient deficiencies, diarrhoeal prevalence, or food allergy. Although it is possible that some dietary component in the maize based diet actually damages the mucosa, it is more likely that there are beneficial nutrients in milk which improve the damaged mucosa, as has been found for some luminal energy substrates of mucosal metabolism. ${ }^{48}$ But if the higher rate of diarrhoea in the milk group could be reduced, such as by reducing the content of lactose in phase 1 milk, then the improvement in permeability of the milk group would be even greater.

METHODOLOGICAL ISSUES

This was not a randomised blinded trial, and there were significant differences between the milk and maize groups in oedema severity and socioeconomic status variables, so the possibility of bias needs to be considered. Socioeconomic variables such as parental schooling, rural residence, water supply, sanitation, employment, and housing were analysed as a socioeconomic score, which was based on validated community data in this region. Both this socioeconomic score and the level of parental schooling had low correlation with L-R permeability in this setting of uniformly low socioeconomic status. Moreover, better educated mothers of higher socioeconomic status would, if anything, have biased results towards improved outcomes in the maize group.

Similarly, seasonal influences would have adversely affected the milk group more than the maize group, as the former were predominantly tested (40/55) during the peak prevalence rainy season of January to April. Figures 1 and 3 display the monthly variations for all kwashiorkor admissions of over five days' duration over 12 months, showing the shorter duration of diarrhoea in hospital and lower weight gain on the maize based diet. HIV infection is another potential bias between groups, but the prevalence of probable or proven AIDS was similar in both treatment groups (table 3).

The mortality for all kwashiorkor admissions during the study period was $30.3 \%$, which decreased to $16.1 \%$ for admissions of more than five days. The mortality for all 149 children with permeability testing was $19.0 \%$, decreasing to $11.9 \%$ for those with repeat tests a week apart. The selection criteria for permeability testing attempted to exclude early deaths so repeat testing could be done, as explained in the previous article. However, there was no systematic selection bias between 
groups tested, as selection followed a prescribed protocol used by the same research assistant, who was unaware of any dietary hypothesis. The differences in mortality between dietary groups (milk $v$ maize) were $13.6 \%(49 / 361) v 20.9 \%(36 / 172)$ for all admissions of more than five days, $13.5 \%$ (10/ 74) $v 26.6 \%(17 / 64)$ for the permeability subjects on one diet, and $3.6 \%(2 / 55) v 22.2 \%$ $(10 / 45)$ for those with repeat testing. The five fewer deaths than expected in the repeat tested milk group $(7 / 55)$ is unexplained by seasonal, early mortality, or selection biases. Although it may be partly a function of small numbers of patients, there may be an even greater benefit of milk in this subgroup with repeat permeability tests. However, the mortality trends clearly indicate a late mortality benefit for the milk group.

It is important to appreciate why this study was not randomised and blinded. Although methodologically desirable, this would have required an enormous change in logistics and in level of nursing care for the nutrition unit to administer both phases of each diet at the same time in a random manner. To have done this would have changed the setting into one atypical of those in which kwashiorkor is actually treated. Taste and appearance differences between the diets made blinding impossible. Our aim in doing the study was to carry it out under the actual conditions at the nutrition centre, rather than transforming it into a metabolic research unit, which would have no external validity for the conditions in poverty stricken areas of Africa where kwashiorkor predominates and is treated. We carried out this study as carefully as possible under difficult circumstances and after thorough examination of the data, have found the results to be robust. The permeability measurements were carried out in a 'gold standard' laboratory in London. We believe that this kind of operational nutritional research can be carried out in settings with high mortality and extremely limited resources, and encourage further similar studies to determine optimal management of childhood malnutrition in the developing world.

\section{Conclusions}

The main finding of this study is that children with kwashiorkor have improved intestinal permeability on a milk diet compared with a maize based diet. This is true in spite of the milk diet causing more diarrhoea, which is a risk factor for abnormal permeability. The late and presumably preventable deaths were also significantly lower in the milk group, both in the 100 cases with repeat permeability testing and also in the 533 kwashiorkor admissions of five or more days on an exclusive milk or maize diet. The poor results with the maize porridge are in spite of germination of the cereal, zinc supplementation, and the addition of soya and egg to the diet. The cause of continuing diarrhoea in kwashiorkor during the early phase of treatment with a milk diet is more likely to be from lactose intolerance than cows' milk allergy. We conclude that milk is superior to a local maize based diet of similar protein and energy density in the treatment of kwashiorkor. Our results warrant exerting pressure on health departments and donor agencies to continue to supply milk powder for the treatment of kwashiorkor.

\section{Key messages}

- Children with kwashiorkor had a lower mortality and better weight gain on the standard milk diet compared with a maize-soya-egg diet

- Diets were similar in protein and energy densities, were supplemented with zinc, and the maize was germinated to increase palatability

- Intestinal permeability improved with nutritional rehabilitation on the milk diet but worsened on the maize diet

- The milk group experienced more initial diarrhoea in hospital, which was due to lactose intolerance rather than cows' milk allergy

- We recommend a low lactose milk based diet in the treatment of kwashiorkor, rather than a local staple diet

1 Quinn VJ, Chiligo-Mpoma MO, Simler K, Milner J. The growth of Malawian preschool children from different growth of Malawian preschool children from differen

2 Mbewe AL. Protein energy malnutrition in Malawian children. [Treatise.] Liverpool: University of Liverpool, 1993.

3 Pretorius PJ, Hansen JD, Davel JGA, Brock JF. Skimmed milk and kwashiorkor. $S$ Afr Med f 1956;33:447-50

4 Waterlow JC. Protein-energy malnutrition. London: Edward Arnold, 1992:1-393.

5 Baker RD, Baker SS, Margo GM, Reuter HH. Successful use of a soya-maize mixture in the treatment of kwashiorkor. S Afr Med F 1978;53:674-7.

6 Brown KH. Appropriate diets for the rehabilitation of malnourished children in the community setting. Acta Paediatr Scand Suppl 1991;374:151-9.

7 John C, Gopaldas T. Evaluation of the impact on growth of a controlled 6-month feeding trial on children (6-24 months) fed a complementary feed of a high energy-low bulk gruel versus a high energy-high bulk gruel in addition to their habitual home diet. F Trop Pediatr 1993;39:16-22.

8 to their habitual home diet. F Frop Pediatr $1993 ; 39: 16-22$. Jalonen T. Identical intestinal permeability changes in chil-
dren with different clinical manifestations of cow's milk dren with different clinical manifestations of

9 Thomas AG, Phillips AD, Walker-Smith JA. The value of

Thomas AG, Phillips AD, Walker-Smith JA. The value of proximal small intestinal biopsy in the differential diag
of chronic diarrhoea. Arch Dis Child 1992;67:741-3.

10 Sullivan PB, Marsh MN. Small intestinal mucosal histology in the syndrome of persistent diarrhoea and malnutrition: a review. Acta Paediatr 1992;81(suppl 381):72-7.

11 Brewster DR, Manary MJ, Menzies IS, O'Loughlin EV, Henry RL. Intestinal permeability in kwashiorkor. Arch Dis Child 1997;76:236-41.

12 Graham GG, Lembcke J, Lancho E, Morales E. Quality protein maize: digestibility and utilization by recovering malnourished infants. Pediatrics 1989;83:416-21.

13 Waterlow JC, Payne PR. The protein gap. Nature 1975;258. 113-7.

14 Golden BE, Golden MH. Plasma zinc, rate of weight gain, and the energy cost of tissue deposition on children recovering from severe malnutrition on a cow's milk or soya protein based diet. Am f Clin Nutr 1981;34:892-9.

15 Doherty J, Jackson AA. The effect of dietary pectin on rapid catch-up weight gain and urea kinetics in children recovering from severe undernutrition. Acta Paediatr 1992;81:5147.

16 Pereira SM, Begum A. The manifestations and management of severe protein-calorie malnutrition (kwashiorkor). World Rev Nutr Diet 1974;19:1-50.

17 Srikantia SG, Gopalan C. Clinical trials with vegetable protein foods in kwashiorkor. Indian $\mathcal{F}$ Med Res 1960;48:63744.

18 Hansen JDL, Schendel HE, Wilkins JA, Brock JF. Nitrogen metabolism in children with kwashiorkor receiving milk and vegetable diets. Pediatrics 1960;25:258-82.

19 Ferguson EL, Gibson RS, Opare-Obisaw C, Ounpuu S, Thompson LU, Lehrfeld J. Zinc nutriture of preschool children living in African countries. F Nutr 1993;123:148796.

20 Roy SK, Behrens RH, Haider R, et al. Impact of zinc supplementation on intestinal permeability in Bangladeshi 
children with acute diarrhoea and persistent diarrhoea syndrome. F Pediatr Gastroenterol Nutr 1992;15:289-96.

21 Ram $\mathrm{N}$. Intake from an energy-dense porridge liquefied by amylase of wheat: a controlled trial in severely malnourished children convalescence from diarrhoea. Eur f Clin Nutr 1994;48:46-53

22 Darling JC, Kitundu JA, Kingamkono RR, et al. Improved energy intakes using amylase-digested weaning foods in Tanzanian children with acute diarrhea. F Pediatr Gastroenterol Nutr 1995;21:73-81.

23 Stephenson DM, Gardner JM, Walker SP, Ashworth A Weaning-food viscosity and energy density: their effects on ad libitum consumption and energy intakes in Jamaican children. Am f Clin Nutr 1994;60:465-9.

24 Cooper ES, Headden G, Lawrance C. Caribbean children, thriving and failing, in and out of hospital. $\mathcal{F}$ Trop Pediatr 1980;26:232-8.

25 Heikens GT, Schofield WN, Dawson SM, Waterlow JC Long-stay versus short-stay hospital treatment of children Long-stay versus short-stay hospital treatment of children suffering from severe prot
Clin Nutr 1994;48:873-82.

26 James WP. Jejunal disaccharidase activities in children with marasmus and with kwashiorkor. Response to treatment. Arch Dis Child 1971;46:218-20.

27 Shulman RJ, Langston C, Lifschitz CH. Histologic findings are not correlated with disaccharidase activities in infants with protracted diarrhea. F Pediatr Gastroenterol Nutr 1991; 12:70-5

28 Romer H, Urbach R, Gomez MA, et al. Moderate and severe protein energy malnutrition in childhood: effects on jejunal mucosal morphology and disaccharidase activities. f Pediatr Gastroenterol Nutr 1983;2:459-64.

29 Phillips AD, Avigid S, Sacks J, Rice SJ, France NE, WalkerSmith JA. Microvillous surface area in secondary disaccharidase deficiency. Gut 1980;21:44-8.

30 Poley JR. The scanning electron microscope: how valuable in the evaluation of small bowel mucosal pathology in chronic childhood diarrhea? Scanning Microsc 1991;5: chronic $1037-62$.

31 Vis HL. On the treatment of certain forms of protein-energy malnutrition in childhood with respect to fatal complications (an example from rural central Africa). Annales Nestle 1985;43:19-30.

32 Brand JC, Darnton Hill I, Gracey MS, Spargo RM. Lactose malabsorption in Australian Aboriginal children. Am $\mathcal{F}$ Clin Nutr 1985;41:620-2.

33 Solomons NW, Torun B, Caballero B, Flores-Huerta S, Orozco G. The effect of dietary lactose on the early recovery from protein-energy malnutrition. I. Clinical and anthropometric indices. Am f Clin Nutr 1984;40:591-600

34 Rothman D, Habte D, Latham M. The effect of lactose on diarrhoea in the treatment of kwashiorkor. 7 Trop Pediatr 1980;26:193-7.
35 Bowie MD, Barbezat GO, Hansen JD. Carbohydrate absorption in malnourished children. Am f Clin Nutr 1967; 20:89-97.

36 Prinsloo JG, Wittmann W, Pretorius PJ, Kruger H, Fellingham SA. Effect of different sugars on diarrhoea of acute kwashiorkor. Arch Dis Child 1969;44:593-9.

37 Ifekwunige AE. Emergency treatment of large numbers of children with severe protein-calorie malnutrition. $A m \mathcal{F}$ Clin Nutr 1975;28:79-83.

38 Walker-Smith JA. Paediatric problems in tropical gastroenterology. In: Cook GC, ed. Gastroenterological problems from the tropics. London: BMJ, 1995:121-9.

39 Msengi AE, Phillips AD, Risdon RA, Walker-Smith JA. Travellers' diarrhoea among children returning to the United Kingdom from visits abroad. Ann Trop Paediatr 1988;8:173-80.

40 Snyder JD. Dietary protein sensitivity: is it an important risk factor for persistent diarrhea? Acta Paediatr 1992;81(suppl 381):78-81

41 Sullivan PB, Marsh MN, Mirakian R, Hill SM, Milla PJ, Neale G. Chronic diarrhoea and malnutrition: histology of the the small intestinal mucosal lesion. F Pediatr Gastroenterol Nutr 1991;12:195-203.

42 Manuel PD. The role of cow's milk protein intolerance in chronic diarrhoea in a developing community. In: WalkerSmith JA, McNeish AS, eds. Diarrhoea and malnutrition in childhood. London: Butterworths, 1986:193-9.

43 Iyngkaran N, Yadav M, Boey CG, Kamath KR, Lam KL. Causative effect of cow's milk protein and soy protein on progressive small bowel mucosal damage. $\mathcal{F}$ Gastroenterol Hepatol 1989;4:127-36.

44 Laudat A, Arnaud P, Napoly A, Brion F. The intestinal permeability test applied to the diagnosis of food allergy in paediatrics. West Indian Med F 1994;43:87-8.

45 Andre C, Andre F, Colin L, Cavagna S. Measurement of intestinal permeability to mannitol and lactulose as a means of diagnosing food allergy and evaluating therapeuic effectiveness of disodium cromoglycate. Ann Allergy 1987;59:127-30.

46 Dupont C, Barau E, Molkhou P, Raynaud F, Barbet JP, Dehennin L. Food-induced alterations of intestinal permeability in children with cow's milk-sensitive enteropathy ability in children with cow's milk-sensitive enteropathy and atop

47 Hagel I, Lynch NR, DiPrisco MC, Lopez RI, Garcia NM. Allergic reactivity of children of different socioeconomic evels in tropical populations. Int Arch Allergy Immunol 1993;101:209-14.

48 Roediger WEW. Metabolic basis of starvation diarrhoea: implications for treatment. Lancet 1986;i:1082-3.

49 van der Hulst RR, Van Kreel BK, Von Meyenfeldt MF, et al. Glutamine and the preservation of gut integrity. Lancet 1993;341:1363-5. 